\title{
Nutritional and physicochemical properties of stored solar-dried cowpea leafy vegetables
}

\author{
H. Natabirwa ${ }^{1}$, J. Mukiibi ${ }^{1}$, E. Zziwa ${ }^{3}$ and J. Kabirizi ${ }^{2}$
}

\author{
${ }^{1}$ National Agricultural Research Laboratories, NARO, P. O. Box 7065, Kampala, Uganda \\ ${ }^{2}$ National Livestock Resources Research Institute, NARO, P. O. Box 31 Tororo, Uganda \\ ${ }^{3}$ Association for Strengthening Agricultural Research in Eastern and Central Africa, P. O. Box 295 \\ Entebbe, Uganda
}

Author for correspondence:

\begin{abstract}
Preservation techniques for cowpea (Vigna unguiculata L.) leaves, a green leafy vegetable mainly consumed in the eastern and northern parts of Uganda, are still lacking. The study aimed at determining the effect of blanching, open sun and solar-drying on the nutrient content, organoleptic acceptability and physicochemical properties of cowpea leafy vegetables (CLV) during storage. Proximate composition, sensory quality and colour of the CLV were determined. No significant differences $(p<0.05)$ in nutrient composition were observed between drying methods, except the dietary fibre, zinc and total carotenoid content. Blanched-solar dried CLV showed higher dietary fibre and total carotenoid content compared to raw dried CLV. No significant differences $(p>0.05)$ in appearance, taste, flavour, and texture of dried CLV were observed, except for the fresh CLV (control). Water activity levels ranged from 0.34 to 0.54 indicative of storage stability. Positive ' $L$ ' colour values (37.90 to 44.95$)$ indicative of light green to green, negative ' $a$ ' values (-7.28 to $\mathbf{- 4 . 1 5 )}$ for greenishness and positive ' $b$ ' values (3.45 to 9.25) for yellowishness for raw-dried and blanched green leafy cowpea vegetable, respectively, were obtained. Marked increases in browning index and total colour difference were observed in the dried CLV during storage. Blanching and solar drying treatment formed stable and highly acceptable vegetables during storage, which could be recommended for market.
\end{abstract}

Key words: Acceptability, colour, nutrient content, Vigna unguiculata, water activity

\section{Introduction}

Green leafy vegetables such as cowpea, are a very important food group in diets of individuals because of their high nutritional value (Faber et al., 2007; Muchoki, 2007; USDA, 2008). They are not only rich in nutrients, but also nutraceuticals and antioxidants such as alpha tocopherol, lycopenes, flavanoids 
and anticancer agents (Shetty et al., 2013). Cowpea leaves are a delicacy to many households especially in the northern and eastern parts of Uganda (Rubaihayo, 1995; Okonya and Maass, 2014). Fresh cowpea leaves are eaten as accompaniments to main dishes, or as sauce and contribute to the health, nutrition, food security and well-being. The vegetables have short growth period, require minimal attention, and are favoured by nutrient-rich soils (Bok et al, 2006; other REF.).

Recommendations have been made to dry and preserve leafy vegetables as a way of ensuring continued supply of food and micronutrients to communities and groups at risk of malnutrition or food insecurity (Kiremire et al., 2010). Sufficient daily consumption of vegetables could help prevent major diseases, such as cardiovascular diseases and certain cancers (WHO, 2013). In this regard, cowpea leafy vegetables (CLV) could be preserved when they are in season and fed to children who are singled out as being at high risk of nutrient deficiency (Faber et al., 2007; WHO, 2013) during periods of scarcity. The water content of most of fresh vegetables including cowpea, however, is above $80 \%$ (FAO, 1995), which limits their shelf-life and makes them more susceptible to storage and transport instability. Processing and preservation methods such as open sun drying and solar drying have been successfully utilized to dry fruits and vegetables such as mushrooms (Addis $e t$ al., 2009). As stated by Singh and Sagar, (2010), processing by dehydration makes leafy vegetables light and can be easily re-converted into fresh-like form for consumption throughout the year.

Even though sun drying is traditionally used to dry steamed cowpea leaves in
Uganda, changes in nutrient and organoleptic attributes as well as storage properties for the dried vegetables, have not been determined. The study was undertaken to evaluate the effect of blanching, open sun drying and solar drying on the nutrient composition, physicochemical properties and acceptability of CLVs.

\section{Materials and methods}

\section{Material source and processing site}

Freshly harvested tender cowpea leaves at 6 weeks after planting, obtained from cowpea farmers in Ngora district, Ngora village, Ngora sub-county in eastern Uganda were processed at a homestead and immediately packaged in HDPE gauge 30 microns. Part of the dried samples packaged in HDPE were delivered to National Agricultural Research Laboratories (NARL), Kawanda Kampala, for proximate, organoleptic and physical tests. Dried and fresh (control) cowpea leaves were organoleptically tested in Ngora, an area where people consume cowpea leaves as a local vegetable, to determine their acceptability.

\section{Sample preparation}

About $2 \mathrm{~kg}$ of fresh green cowpea leaves, free from insect damage, plucked from plant stalks, were washed in plenty of clean rain water which was available at the study site to remove dirt and spread on a raised wire-mesh to drain excess water. The leaves divided into four portions for blanching in water or no blanching, and then drying.

\section{Processing}

a) Blanching. Clean cowpea leaves (1 $\mathrm{kg}$ ) were placed in a clean saucepan of 
$30 \mathrm{~cm}$ diameter, containing $250 \mathrm{ml}$ of boiling water, covered with a lid, and blanched for 5 minutes on a hot charcoal stove with occasional stirring. After 5 minutes, the CLVs were removed from the charcoal stove and spread on a plastic drying wire-mesh.

b) Drying. The raw unblanched and the blanched cowpea leaves were each subdivided into two. The leaves were spread on $2 \mathrm{~m}^{2}$ plastic wire-mesh drier racks and dried either in the open sunshine or solar drier to moisture content $6.0-8.7 \%$ when both the leaves and stalks were completely dry and easy to crush to tiny pieces. The drying time was 9-12 hours on hot sunny days and $21-24$ hours during the wet days.

(c) Packaging. Dried CLVs, were packaged in high density polythene of gauge 200, immediately upon removal from the sunshine; and sealed to prevent moisture re-absorption. The packaged vegetables were kept at room temperature in dark-coloured blue buckets to protect from light.

\section{Physicochemical and nutrient analysis} Moisture was determined by drying approximately $2.0 \mathrm{~g}$ of fresh sample in a hot air oven at $105^{\circ} \mathrm{C}$ for 2 hours following specified methods (Ranganna, 1986; AOAC, 1999; FSSAI, 2012). Dry matter content was calculated by difference. Fat, total carbohydrates, dietary fibre, ash and protein were determined using AOAC (1999; 2005) methods. Fat was determined by the Soxhlet method; total carbohydrate by a spectrophotometric method; dietary fibre by the acid digestion method; ash by the ashing method at $250^{\circ} \mathrm{C}$ for 6 hours; protein by the MicroKjeldahl method and the percentage of nitrogen was converted to crude protein by multiplying by 6.25 . Micronutrients iron, phosphorus, zinc, magnesium, calcium, sodium and potassium were determined by atomic absorption spectrophotometric method (AOAC, 1999) using Atomic absorption Spectrophotometer (Buck Scientific model 200A).

Colour was determined according to Abbott (1999) and Pankaj et al. (2013). The colour was measured using a Minolta Colour meter, Model CR 10, and values $\mathrm{L}$, $\mathrm{a}$, and $\mathrm{b}$ were determined where ' $\mathrm{L}$ ' indicated lightness, 'a' the degree of red $(+a)$ and greenness $(-a)$; while ' $b$ ' indicated yellow (+b) and blue (-b) colour ranges (Martins et al., 2002; Pathare et al, 2013). The browning index and total colour difference (TCD) were calculated based on methods reported (Pathare et al., 2013).

Browning index $=100 X\left(\frac{(X-0.31)}{0.17}\right)$

Where:

$$
X=\frac{(a *+1.75 L) a}{(5.645 L+a *-3.012 b *)}
$$

Water activity was determined at ambient conditions, using a Bench-top Water Activity Meter, Model AquaLab, Series 4TE.

\section{Acceptability}

The acceptability of the CLV was determined using a 24-member controlled panel. Cooked freshly harvested CLV were used as a control. Samples were prepared for panel testing using a traditional preparation method used in the north and eastern of Uganda. Approximately one mug of thinly crushed dry cowpea leaves was poured into 2000 
$\mathrm{ml}$ of clean boiling rain water, to which 20 $\mathrm{ml}$ of 'legume plant extract, also known as 'kado-buru' or 'kedo-atwona' in Luo, was added to enhance softening of the leaves during cooking. Fresh harvested CLV (about $0.2 \mathrm{~kg}$ ) were spread in sunshine for about 40 minutes as a pretreatment prior to boiling in water. The leaves were cut using a sharp stainless steel knife into small pieces $(\sim 2 \mathrm{~cm})$ and boiled in $2000 \mathrm{ml}$ rain water containing 'kedo-atwona' for approximately 30 minutes until ready and placed aside.

Regular consumers of cowpea vegetables were selected as panelists. Small portions (about 3 table-spoonfuls) of cooked samples were served to the panelists at ambient temperature $(25-27$ $\left.{ }^{\circ} \mathrm{C}\right)$. Panelists tested the appearance, taste, flavor, texture and overall acceptability of CLV by rating them on a 9-point hedonic scale, where, 9=liked extremely and $1=$ disliked extremely.

\section{Statistical analysis}

Mean and standard deviations were generated using SAS (2000) and XLSTAT (2012). Duncan's multiple range test was used to assess the mean significant differences at $p £ 0.05$. Coefficients of variation were generated using XLSTAT.

\section{Results and discussion}

\section{Nutrient composition}

Tables 1 and 2 show the nutrient conmposition for dried cowpea leafy vegetables (CLV). Raw open sun-dried CLVs contained higher iron, zinc and total carotenoid than other treatments. No significant differences $(p>0.05)$ were observed in moisture, protein, carbohydrate, fat and ash contents. Iron, calcium and phosphorus content were not significantly different $(P>0.05$. The magnesium, zinc and total carotenoid contents, however, were significantly different $(p<0.05)$ among treatments. The high iron content in open sun-dried CLVs might be due to contamination with dust from the environment, which also has been reported by Singh et al. (2010). The differences in provitamin A carotenoid content might be due to losses during drying and heat pre-treatment. Total provitamin A carotenoids, as explained by Addis et al. (2009), are significantly reduced by drying methods.

The iron, phosphorus, potassium and calcium composition for dried cowpea leaves were not significantly different ( $p$ $<0.05$ ), except the magnesium, zinc and total carotenoid content (Table 2). This

Table 1. Proximate macronutrient composition for the dried cowpea leafy vegetable

\begin{tabular}{lcccccc}
\hline Vegetable type & $\begin{array}{c}\text { Moisture } \\
(\mathrm{g})\end{array}$ & $\begin{array}{c}\text { Protein } \\
(\mathrm{g})\end{array}$ & $\begin{array}{c}\text { Carbo- } \\
\text { hydrates } \\
(\mathrm{g})\end{array}$ & Fat $(\mathrm{g})$ & $\begin{array}{c}\text { Fibre } \\
(\mathrm{g})\end{array}$ & $\begin{array}{c}\text { Ash } \\
(\mathrm{g})\end{array}$ \\
\hline Blanched, solar dried cowpea leaves & $6.31^{\mathrm{a}}$ & $28.07^{\mathrm{b}}$ & $21.65^{\mathrm{ab}}$ & $1.92^{\mathrm{ab}}$ & $29.48^{\mathrm{a}}$ & $11.00^{\mathrm{a}}$ \\
Blanched, open sundried cowpea leaves & $7.04^{\mathrm{a}}$ & $29.09^{\mathrm{ab}}$ & $20.73^{\mathrm{ab}}$ & $2.28^{\mathrm{a}}$ & $29.31^{\mathrm{a}}$ & $10.67^{\mathrm{a}}$ \\
Raw, open sundried cowpea leaves & $7.35^{\mathrm{a}}$ & $30.12^{\mathrm{a}}$ & $20.12^{\mathrm{b}}$ & $1.90^{\mathrm{ab}}$ & $19.57^{\mathrm{b}}$ & $10.84^{\mathrm{a}}$ \\
Raw, solar dried & $7.29^{\mathrm{a}}$ & $29.40^{\mathrm{ab}}$ & $23.56^{\mathrm{a}}$ & $1.68^{\mathrm{b}}$ & $17.10^{\mathrm{b}}$ & $10.60^{\mathrm{a}}$ \\
\hline
\end{tabular}

* Values followed by the same superscript letter with a column are not significantly different 

effect on micronutrient content, apart from $\mathrm{Mg}, \mathrm{Zn}$ and total carotenoids. High $\mathrm{Zn}$ content in open sun-dried CLV was probably due to air contamination.

\section{Water activity}

The water activity, $a_{w}$, for CLV (Fig. 1) was not significantly different among treatments $(P>0.05) . a_{w}$ values $£ 0.6$, attained within the different treatments were sufficient enough to keep the vegetables in dry condition once well packaged (Cano-Chauca et al, 2004). The level was within the range $(<0.6)$ permitted for storage and preservation of dry foods as suggested by FAO (1995) and CanoChauca et al. (2004). As explained FAO, 1995; Bonazzi and Dumoulin, 2011), low moisture and water activity $(<0.5)$ are important to prevent physical-chemical and microbiological alterations that could occur during storage of a food product, hence ensuring product preservation.

Differences in water activity content were possibly due to re-absorption or loss of moisture during storage. No significant differences $(p>0.05)$ were observed in water activity for dried packaged CLVs during storage between zero and one month (Fig. 1). Results possibly indicate shelf-stable products that would not be prone to fungal attack and spoilage.

\section{Colour}

Colour is an important quality attribute of food, which influences consumers' choice and preferences (Pathare et al, 2013). Colour measurement of food has been used as an indirect measure of other quality attributes, such as flavour and contents of pigments because it is simpler, faster and correlates well with other 


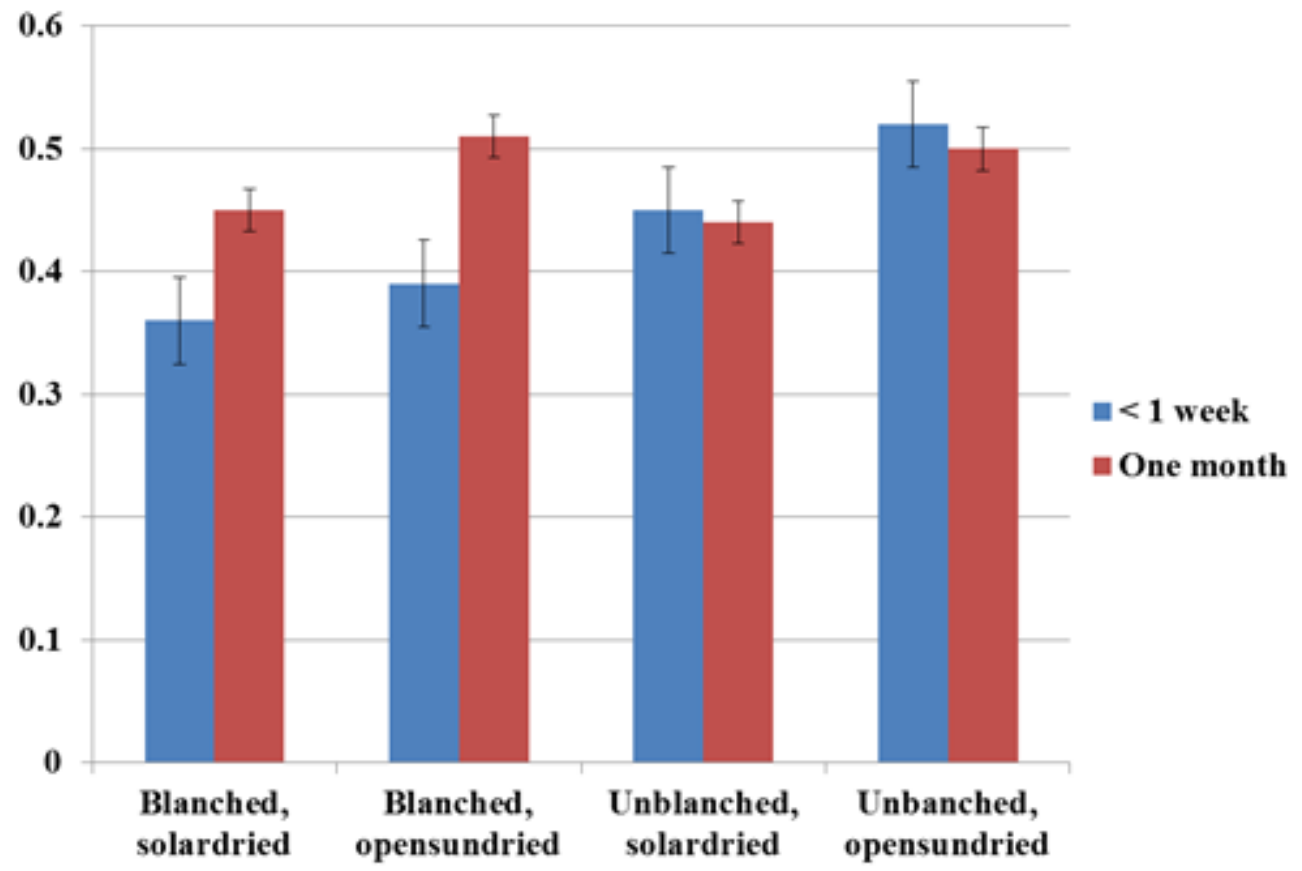

Figure 1. Effect of processing method and storage duration on water activity of dried cowpea vegetables.

physicochemical properties, such as appearance (Pathare et al, 2013).

Changes in colour were not definite after one month, save for the rise in $\mathrm{L}^{*}$ and $b^{*}$ values (Table 3 ). An increase in the positive $b^{*}$ values was a result of loss in colour (increasing yellowness) during drying, which could be explained by the loss of pigments such as chlorophyll and carotenoids from the leaves, caused by the two processes, blanching and drying (Kidmose et al., 2005). Positive increase in $\mathrm{a}^{*}$ values (i.e. reduction in negative $\mathrm{a}^{*}$ values) was noticeable after storage of one month, which could be indicative of loss of the green colour and a result of browning upon processing and storage. In general, raw dried vegetable leaves were lighter green (higher ' $L$ ' values; (increasingly -ve 'a' "values) and yellow (higher $+b^{*}$ values) than blanched cowpea leaves after drying. Dried blanched vegetable leaves were dark (high $+v e$ ' $a$ ' and more $-v e$ ' $b$ ' values) after drying compared to fresh uncooked leaves; this was also confirmed with negative 'Hue' values and high Total Colour Differences (TCD). The dark colour in blanched CLVs could be explained by retention of plant pigments and the destruction of browning enzymes in blanched leaves, which would otherwise cause browning (Pathare et al, 2013).

Large negative browning index values were observed in 'dried raw' compared to 'dried blanched' vegetables (Table 3). The large negative browning index values could be due to the increase in formation of brown pigments by enzymatic browning, as well as oxidation reactions enhanced by sunshine in unblanched CLVs (Pathare et al, 2013). Largely negative browning indices could further be explained by the long duration of exposure 
Table 3. Mean values ( \pm SErrors) for colour changes in dried cowpea leafy vegetables during storage

\begin{tabular}{|c|c|c|c|c|c|c|c|}
\hline $\begin{array}{l}\text { Type of vegetable } \\
<1 \text { week after drying }\end{array}$ & $\mathrm{L}$ & a & $\mathrm{b}$ & $\begin{array}{l}\text { Yellowness } \\
\text { index }\end{array}$ & $\begin{array}{l}\text { Browning } \\
\text { index }\end{array}$ & $\mathrm{TCD}^{1}$ & Hue \\
\hline Raw solar dried & $44.80 \pm 1.62^{\mathrm{a}}$ & $-6.65 \pm 0.40^{b}$ & $9.25 \pm 1.10^{\mathrm{a}}$ & $29.43 \pm 2.44^{\mathrm{a}}$ & $-1467.87 \pm 89.65^{\mathrm{b}}$ & $6.87 \pm 1.97^{\mathrm{a}}$ & $-6.31 \pm 2.83^{\mathrm{b}}$ \\
\hline Blanched, solar dried & $37.90 \pm 1.16^{\mathrm{b}}$ & $-4.25 \pm 0.17^{\text {a }}$ & $3.950 .17^{\mathrm{b}}$ & $14.88 \pm 0.20^{\mathrm{b}}$ & $-966.93 \pm 32.23^{\mathrm{a}}$ & $2.96 \pm 0.53^{b}$ & $-1.34 \pm 0.01^{\mathrm{a}}$ \\
\hline Raw, open sun dried & $45.60 \pm 0.14^{\mathrm{a}}$ & $-7.28 \pm 0.13^{c}$ & $9.00 \pm 0.26^{\mathrm{a}}$ & $28.19 \pm 0.75^{\mathrm{a}}$ & $-1573.98 \pm 6.77^{c}$ & $7.61 \pm 0.23^{\mathrm{a}}$ & $-2.89 \pm 0.17^{\mathrm{a}}$ \\
\hline Blanched open sun dried & $39.30 \pm 0.23^{\mathrm{b}}$ & $-4.15 \pm 0.06^{\mathrm{a}}$ & $3.45 \pm 0.17^{\mathrm{b}}$ & $12.54 \pm 0.56^{\mathrm{c}}$ & $-943.37 \pm 12.01^{\mathrm{a}}$ & $3.25 \pm 0.13^{b}$ & $-1.10 \pm 0.07^{\mathrm{a}}$ \\
\hline After one month storage & & & & & & & \\
\hline Raw solar dried & $43.90 \pm 1.16^{\mathrm{a}}$ & $-6.55 \pm 0.06^{c}$ & $8.500 .35^{\mathrm{a}}$ & $27.65 \pm 0.40^{\mathrm{a}}$ & $-1437.81 \pm 14.60^{c}$ & $5.73 \pm 1.19^{\mathrm{a}}$ & $-3.630 .58^{b}$ \\
\hline Blanched, solar dried & $42.15 \pm 0.29^{b}$ & $-5.80 \pm 0.12^{b}$ & $7.50 \pm 0.02^{\mathrm{b}}$ & $25.42 \pm 0.17^{\mathrm{c}}$ & $-1288.88 \pm 20.38^{\mathrm{b}}$ & $3.66 \pm 0.28^{\mathrm{b}}$ & $-3.540 .35^{\mathrm{b}}$ \\
\hline Raw, open sun dried & $45.15 \pm 1.33^{\mathrm{a}}$ & $-6.45 \pm 0.17^{c}$ & $8.400 .46^{\mathrm{a}}$ & $26.56 \pm 0.68^{b}$ & $-1416.26 \pm 36.90^{c}$ & $6.84 \pm 1.42^{\mathrm{a}}$ & $-3.680 .53^{b}$ \\
\hline Blanched open sun dried & $39.38 \pm 0.57^{c}$ & $-4.25 \pm 0.19^{\mathrm{a}}$ & $3.580 .32^{\mathrm{c}}$ & $12.96 \pm 1.05^{\mathrm{d}}$ & $-962.32 \pm 36.57^{\mathrm{a}}$ & $3.15 \pm 0.27^{\mathrm{b}}$ & \\
\hline \multicolumn{8}{|c|}{ Values with the different superscript letters in the same columns are significantly different $(\mathrm{p}<0.05)$} \\
\hline
\end{tabular}


Table 4. Organoleptic scores for cooked dried cowpea leafy vegetables used in a drying and storage study Ngora, Uganda

\begin{tabular}{lccccc}
\hline Cowpea leaves type & \multicolumn{5}{c}{ Attribute scores } \\
\cline { 2 - 6 } & Appearance & Taste & Flavour & Texture & $\begin{array}{c}\text { Overall } \\
\text { acceptability }\end{array}$ \\
\hline Blanched, solar dried & $6.458^{\mathrm{b}}$ & $6.708^{\mathrm{b}}$ & $6.208^{\mathrm{b}}$ & $5.625^{\mathrm{b}}$ & $6.542^{\mathrm{b}}$ \\
Blanched, open sun-dried & $6.125^{\mathrm{b}}$ & $5.917^{\mathrm{b}}$ & $5.458^{\mathrm{b}}$ & $4.542^{\mathrm{b}}$ & $5.833^{\mathrm{b}}$ \\
Raw, solar dried & $6.708^{\mathrm{b}}$ & $5.833^{\mathrm{b}}$ & $5.625^{\mathrm{b}}$ & $5.042^{\mathrm{b}}$ & $5.667^{\mathrm{b}}$ \\
Raw, open sun-dried & $6.542^{\mathrm{b}}$ & $6.083^{\mathrm{b}}$ & $5.500^{\mathrm{b}}$ & $5.500^{\mathrm{b}}$ & $6.292^{\mathrm{b}}$ \\
Fresh leaves (control) & $8.250^{\mathrm{a}}$ & $7.875^{\mathrm{a}}$ & $7.708^{\mathrm{a}}$ & $7.333^{\mathrm{a}}$ & $7.958^{\mathrm{a}}$ \\
\hline
\end{tabular}

to sunshine (Demirhan et al., 2009), of vegetables under drying. It is notable that the drying time ranged between 9 to 24 hours depending on the weather. Lengthy drying time was possibly contributory to browning reactions in CLV.

\section{Acceptability}

Sensory evaluation could be considered the most important aspect of food quality. It reflects consumer preference. Sensory evaluation of vegetables brings about very valuable information on quality characteristics and level of acceptability with a consequence on adoption potential. According to Abbot (1999) and Eze et al. (2012), sensory traits of vegetables are the main factors that determine consumer's satisfaction.

Apart from the control, dried cowpea leaves were not significantly different $(p$ $>0.05$ ) in appearance, taste, flavour, texture and overall acceptability. Blanched solar dried CLVs were comparatively more acceptable in taste, flavour and texture than the blanched open sun dried, raw-sundried and raw-solar dried CLVs. Blanched solar dried CLVs were however less acceptable than the control, which may explain the negative effects of processing on leafy vegetable taste and flavour changes. Sensory tests showed that panelists liked blanched solar dried CLV especially for its taste and flavor. Raw-dried CLVs were moderately liked for appearance, but only slightly liked for flavour, taste and texture. This could be explained by the deterioration in taste, flavour and texture of vegetables due to open sun drying (Addis et al., 2009) and enzymatic reactions (Kidmose et al., 2005).

The relatively natural green colour after cooking could explain the average high appearance scores for un-blanched leafy vegetables. This finding relates to results of the colour (Table 4), whereby raw dried leafy cowpea leaves featured with high positive ' $b$ ' values indicative of green. Analysis of variance showed that taste and texture were important in deciding the acceptability of dry processed vegetables $(\mathrm{p}<0.05)$. Overall, blanched solar dried cowpea leafy vegetables were liked more than the other treatments.

\section{Conclusion}

Blanching combined with solar drying enriches the taste, flavor, texture and storage stability of cowpea leafy vegetables (CLVs), but not the 
appearance and colour. Blanched CLVs are highly acceptable, implying that blanching is a necessary pre-treatment in vegetable drying, which enhances flavour, taste and texture.

Solar drying and open sun drying technologies result into moisture-stable and low water activity which can ensure stability of dried vegetables even after drying. Preservation of leafy vegetables using open sun or solar drying should preferably be done when the sunshine is intense enough to cause fast drying, prevent browning and loss of flavours.

\section{Acknowledgement}

The authors would like to thank the Association for Strengthening Agricultural Research in Eastern and Central Africa (ASARECA) for funding the research. We acknowledge the management and support by the National Livestock Resources Research Institute (NaLIRRI) of NARO, Uganda. This work is a product of the Food BioSciences and Agribusiness Research Program of the National Agricultural Research Laboratories (NARL) and National Livestock Resources Research Institute, both of NARO, Uganda.

\section{References}

Abbott, J.A. 1999. Quality measurement of fruits and vegetables. Journal of Postharvest Biology and Technology 15:207-225.

Addis, G., Baskaran, R., Raju, M., Ushadevi, A., Asfaw, Z., Woldu, Z. and Baskaran, V. 2009. Effect of blanching and drying process on carotenoids composition of underutilized Ethiopian (Coccinia Grandis L. Voigt) and Indian (Trigonella Foenum-Graecum
L.) green leafy vegetables. Journal of Food Processing and Preservation 33:744-762.

AOAC, 1999. Association of Official Analytical Chemists (AOAC). Official Methods of Analysis, 15th edition, Washington DC, USA.

AOAC, 2005. Official Methods of Analysis of the Association of Official Analytical Chemists, Washington D.C., USA. $18^{\text {th }}$ ed.

Bonazzi, C. and Dumoulin, E. 2011. Quality changes in Food materials as influenced by drying processes. Modern Drying Technology. Vol. 3: Product Quality and Formulation, First Edition, Tsotsas, E. and Mujmdar, A.S. (ed.). Wiley-VCH Verlag GmbH \& KgaA Publ.

Cano-Chauca, M., Afonso, M., Ramos, P.C. Stringheta1 and José A.M Pereira 2004. Drying curves and water activity evaluation of dried banana. Drying Proceedings of the 14th International Drying Symposium (IDS 2004). São Paulo, Brazil, 22-25 August 2004, vol. C, pp. 2013-2020.

Chang, S.K., Nagendra, P.K. and Amin, L. 2013. Carotenoids retention in leafy vegetables based on cooking methods. International Food Research Journal 20(1):457-465.

Demirhan, E. and Ozbek, B. 2009. Color change kinetics of microwave-dried basil. Drying Technology 27(1):156166.

Eze S.C., Baiyeri, K.P. and Agbo, C.U. 2012. Sensory evaluation response as a selection tool in African eggplant (Solanum aethiopicum) production and breeding. African Journal of Agricultural Research 7(37):52475251.

Faber, M., Van Jaarsveld, P.J. and Laubscher, R. 2007. The contribution 
of darkgreen leafy vegetables to total micronutrient intake of two-five-year old children in a rural setting. Water SA. 33(3):407 - 412.

FSSAI [Food Safety \& Standards Authority of India], 2012. Manual of methods for Analysis of Foods. Cereal and Cereal Products. Laboratory Manual No.3. Min. of Health and Family Welfare. Government of India, New Delhi. Draft Publ.

Kidmose, U., Edelenbos, M., Christensen, L.P. and Hegelund, E. 2005. Chromatographic determination of changes in pigments in spinach (L.) during processing. Journal of Chromatographic Science 43(9):466 -472 .

Kiremire, B.T., Musinguzi, E.L., Kikafunda, J.K. and Lukwago, J.B. 2010. Effects of vegetable drying techniques on nutrient content: A case study of south-western Uganda. African Journal of Food Agriculture and Nutrition Development 10 (5):2587 - 2600.

Martins, R.C. and Silva, C.L.M. 2002. Modelling colour and chlorophyll losses of frozen green beans (Phaseolus vulgaris L.). International Journal of Refrigeration 25: 966-974.

Muchoki, C.N. 2007. Changes in betacarotene, ascorbic acid and sensory properties in fermented, solar-dried and stored Cowpea leafy vegetables. African Journal of Food, Agriculture, Nutrition and Development 3 and 4:16 - 26.

Okonya J.S. and Maass B.L. 2014. Protein and Iron composition of cowpea leaves: an evaluation of sic cowpea varieties grown in Eastern Africa. African Journal of Food Agriculture Nutrition and Development 14 (5):9329 - 9340.
Pathare P.B., Umezuruike L., Opara and Fahad Al-Julanda Al-Said, 2013. Colour measurement and analysis in fresh and processed foods: A review. Food Bioprocess Technology 6:3660.

Ranganna, S. 1986. Handbook of Analysis and Quality Control for Fruit and Vegetable products. $2^{\text {nd }}$ Ed. Tata McGraw-Hill publishing Co., Limited, New Delhi, India. 1112 p. Reprinted, 2008.

Rubaihayo, E. B. 1995. Conservation and use of traditional vegetables in Uganda. Proceedings of the IPGRI International Workshop. Genetic Resources and Traditional Vegetables Africa Conservation Use, Nairobi, Kenya, 29-31 August, 1995.

Shetty, A.A., Magadum, S. and Managanvi, K. 2013. Vegetables as sources of antioxidants. Journal of Food and Nutritional Disorders 2:1.

Singh, U. and Sagar, V.R. 2010. Quality characteristics of dehydrated leafy vegetables influenced by packaging materials and storage temperature. Journal of Scientific \& Industrial Research $785-789$.

Statistical Analysis System (SAS). 2000. Version 8.1, User Guideline, Statistical Analysis Institute, Inc. Cry. USA. $1028 p p$.

USDA, 2008. Increasing fruit and vegetable consumption through the USDA Nutrition Assistance Program. A Progress Report. Food and Nutrition Service Publ.

WHO, 2013. Promoting fruit and vegetable consumption around the world. Global Strategy on Diet, Physical Activity and Health. www.who.int/dietphysicalactivity/fruit/ 